\title{
Temporal and Axial Variations for Secondary Nutrient Concentrations in Leaves of Litchi
}

\author{
Ragini Kumari $^{1 *}$, Prabhakar Mahapatra ${ }^{2}$ and Sunil Kumar ${ }^{1}$ \\ ${ }^{1}$ Department of Soil Science and Agricultural Chemistry, Bihar Agricultural University, \\ Sabour (Bhagalpur) - 813210 (Bihar/India) \\ ${ }^{2}$ Department of Soil Science and Agricultural Chemistry, Birsa Agricultural University, \\ Ranchi - 834006 (Jharkhand/India) \\ *Corresponding author
}

\begin{abstract}
A B S T R A C T
Keywords

Leaf analysis, Litchi, Secondary nutrient, Temporal and axial variation and Correlation coefficient

Article Info

Accepted:

15 May 2019

Available Online:

10 June 2019

Litchi is one of the important subtropical fruit crops in the state of Jharkhand, occupying around 3.3 thousand hectare and production is about 16.5 thousand metric tonnes. Considering the importance of plant analysis in fruit crops, the present investigation was carried out in an established orchard (since, 1979) at ICAR Research Complex for Eastern Region, Ranchi Centre to study the nutrient concentration in leaves of Litchi orchard as well as interrelationship between available nutrients present in leaf with crop productivity for developing a sound fertilizer management programme. Collection of leaf samples from established orchard was done during the 2006-07; analysis of leaf samples for secondary nutrients $(\mathrm{Ca}, \mathrm{Mg}$ and $\mathrm{S}$ ) in plant (leaf) part was carried out. The concentration of secondary nutrients varied from 0.099 to $0.225,0.050$ to 0.114 and 0.070 to 0.076 percent for $\mathrm{Ca}, \mathrm{Mg}$ and $\mathrm{S}$, respectively. However, mean leaf nutrient concentration was 0.162 , 0.082 and 0.073 percent for $\mathrm{Ca}, \mathrm{Mg}$ and $\mathrm{S}$, respectively. Highest concentration of $\mathrm{Ca}, \mathrm{Mg}$ and $\mathrm{S}$ was observed for the $4^{\text {th }}$ pair of leaves. Significant negative relationship between yield and concentration were observed in $2^{\text {nd }}$ and $4^{\text {th }}$ pair of leaves.
\end{abstract}

\section{Introduction}

Jharkhand state (India) is emerging as a potential region for litchi cultivation because of its suitable climatic condition. The rolling uplands of Jharkhand have been found to be highly suitable for the good crop of litchi (Rai et al., 2002). Bhargava (2002) suggested that leaf analysis was the best method to ensure high economic productivity, to identify the need for application of nutrients, to sustain the available soil nutrient status at a desirable level, correct doses of manures, bio-fertilizers and chemical fertilizers that must be applied in perennial fruit crops. Leaf analysis seems to be the best method for identifying the need for application of nutrients or diagnosing nutritional problems and a basis for fertilizer recommendation for fruit trees in many countries (Shear and Faust, 1980). The present investigation is planned to establish the status of secondary nutrients $(\mathrm{Ca}, \mathrm{Mg}$ and 
S) with temporal and axial effects in leaves of litchi around the year for the purpose of application of appropriate fertilizer to improve quality and productivity of litchi. By comparing the results of the analysis of leaf samples, suspected nutrient deficiencies can be confirmed or rejected.

\section{Materials and Methods}

Horticulture \& Agro Forestry Research Programme (HARP), Plandu, Ranchi formerly known as Central Horticultural Experiment Station (CHES) was the site of experimentation. It was situated at Plandu in the district of Ranchi, capital of Jharkhand state. Geographically, HARP is located at the latitude $23^{\circ} 15^{\prime}$ and $23^{\circ} 18^{\prime}$ North and longitude of $85^{\circ} 25^{\prime}$ East and at an elevation of 625 meters above mean sea level.

The climate of the station is humid to subtropical type. The temperature ranges from a maximum of 30 to $34{ }^{\circ} \mathrm{C}$ in April to June and a minimum of about 9 to $10{ }^{\circ} \mathrm{C}$ in December and January. The mean annual precipitation was about $1473 \mathrm{~mm}$, out of which roughly $3 / 4^{\text {th }}$ was received during June to September from south west monsoon.

Twenty plants of litchi (10 plants each of Shahi and China) were selected randomly for leaf nutrient analysis from the experimental farm of HARP. Leaf samples were collected from $6^{\text {th }}$ March 2006 to $6^{\text {th }}$ February 2007 and sample were taken on $6^{\text {th }}$ day of every month from the same randomly selected plants.

The leaves were collected from the midsection of terminal shoots located on different sides of the tree. Leaves were collected from the interior portion of the tree at shoulder height or higher, no more than two leaves from any one shoot. Thirty leaves were collected from a single tree and the different pairs of leaves were separated. Total no of leaf samples were nine hundred sixty.
Fertilizers used during 2006-2007 were 80100 kg FYM, 3-4 kg karanj cake, $1.7 \mathrm{~kg}$ urea, $2.5 \mathrm{~kg}$ ssp and $0.66 \mathrm{~kg}$ mop per tree. Applications of FYM, potassic, phosphatic and $2 / 3^{\text {rd }}$ dose of $\mathrm{N}$ were done during JuneJuly; just after harvesting the fruit and remaining $1 / 3^{\text {rd }}$ were applied after fruit set in the month of March-April. After applications of fertilizer, trees were irrigated to maintain proper soil moisture. Fertilizers were applied through in a ring between 150 and $200 \mathrm{~cm}$ distance from the trunk. Data were statistically analyzed. The experiment was laid out in Randomized Block Design.

The leaf samples were washed with acidified detergent solution (Bhargava, 2002), rinsed in doubled distilled water, dried in hot air circulation oven at $65^{\circ} \mathrm{C}$ till constant weight was obtained and ground in stainless steel blade Waring blender. The powdered samples were stored in polythene bags.

Total $\mathrm{Ca}, \mathrm{Mg}$ and $\mathrm{S}$ were estimated after digestion in di-acid mixture $\left(\mathrm{HNO}_{3}: \mathrm{HClO}_{4}\right.$ 10:4 ratio) using the standard methods. $\mathrm{Ca}$ and $\mathrm{Mg}$ were determined titrimetrically with the help of versenate titration method (Hesse, 1971) and Sulpher was determined turbidimetrically as described by Chesnin and Yien, 1950.

\section{Results and Discussion}

The mean nutrient concentrations of leaf samples collected in 2006-2007 from Litchi orchards and were summarized according to time period. Some of the differences in the nutrient concentrations over the year in this data were also associated with the variability among the trees and different cultivars. These variations in nutrient concentration of the leaf samples indicate the physiological need of litchi at different stages of growth and development. The results were based on the following factors mainly which were 
associated with the litchi plants and environments.

\section{Temporal variability in leaf calcium} concentration

It is evident from Table 1 , mean leaf $\mathrm{Ca}$ concentration varied from 0.099 to $0.225 \%$. The highest concentration $(0.225 \%)$ was recorded in the month of February and lowest concentration $(0.099 \%)$ was recorded in the month of March. Concentration observed during the year differed among them significantly. These results were in line with those of Menzel et al., (1992 b) and Huang et al., (1998) suggested that leaf $\mathrm{Ca}$ concentration for litchi in Australia and Taiwan was in the range of $0.60-1.00 \%$. Sanyal and Mitra (1990) suggested that leaf $\mathrm{Ca}$ concentration was increased as the leaves matured in Litchi.

Perusal of the results mean $\mathrm{Ca}$ concentration reflected that the leaf $\mathrm{Ca}$ concentration increased throughout the month from April to February; however, magnitude of the increase was not similar and decreased significantly in the month of March. A steady increase in leaf $\mathrm{Ca}$ concentration with advancement of age might be due to the continuous accumulation of these nutrients through transpiration stream due to larger leaf area or might be possibly due to relative immobility of these nutrient elements or $\mathrm{Ca}$ being less mobile in plant and due to its role in cell wall synthesis. Present studies were also corroborated by the findings of Battelli and Renzi (1990), Laupassaki et al., (1997) in Kiwifruit. And Menzel et al., (1987) in leaves of litchi cv. Bengal.

\section{Axial variability in leaf calcium concentration}

Data in Table 1 indicates that $4^{\text {th }}$ pair of leaves showed maximum $\mathrm{Ca}$ concentration and followed by $3^{\text {rd }}, 2^{\text {nd }}$ and $1^{\text {st }}$ pair of leaves respectively. Ca concentration in $4^{\text {th }}$ pair of leaves imposed its superiority over other pairs. Similar trend was observed by Khera et al., (1981) in leaves of Peach, Sanyal and Mitra (1990) in litchi leaf cv. Bombai.

\section{Correlation coefficient between leaf calcium concentration and crop productivity}

In Table 2, correlation coefficient values indicated that fruit yield was negatively and significantly correlated with Calcium. Highest significant negative correlation $\left(-0.812^{* *}\right)$ was observed with $2^{\text {nd }}$ pair of leaves in the month of December.

\section{Temporal variability in leaf magnesium concentration}

Data presented in Table 3 indicate that highest $\mathrm{Mg}$ concentration $(0.114 \%)$ was recorded in the month of February and lowest concentration $(0.050 \%)$ in the month of March. However, it varied from 0.050 to $0.114 \%$. This finding of present investigations was supported by Menzel et al., (1992 b) and Huang et al., (1998). They suggested that leaf nutrient concentration for litchi in Australia and Taiwan was $0.30-0.50 \%$. Statistically, significant decrease was recorded in the month of March \& December and significant increase was recorded in the month of January, February, May, June, August, September and November. Concentration recorded in the month of March-April, JuneJuly and September-October remained at par.

It clearly shows that a continuous increase in concentration was recorded from April to November and a decrease in December and rose slightly in January and February.

A steady increase in leaf $\mathrm{Mg}$ concentration with advancement of age might be due to for photosynthesis to meet the need of the 
growing tissues besides transactions of photosynthates and accumulation in different plant parts and storage organs. Sanyal and Mitra (1990) suggested that leaf $\mathrm{Mg}$ concentration increased as the leaves matured in litchi fruits. Present studies were also corroborated by the findings of Battelli and Renzi (1990) and Laupassaki et al., (1997) in Kiwifruit, Porro et al., (1995) in Grapes, Menzel et al., (1987) in leaves of litchi cv. Bengal.

\begin{tabular}{|c|c|c|c|c|c|}
\hline \multicolumn{7}{|c|}{ Table.1 } \\
\hline Month & $1^{\text {st }}$ pair & $2^{\text {nd }}$ pair & $3^{\text {rd }}$ pair & $4^{\text {th }}$ pair & Mean \\
\hline Jan & 0.194 & 0.203 & 0.214 & 0.222 & 0.208 \\
\hline Feb & 0.210 & 0.219 & 0.230 & 0.240 & 0.225 \\
\hline Mar & 0.082 & 0.092 & 0.101 & 0.119 & 0.099 \\
\hline Apr & 0.093 & 0.101 & 0.110 & 0.125 & 0.107 \\
\hline May & 0.100 & 0.110 & 0.119 & 0.133 & 0.116 \\
\hline Jun & 0.108 & 0.119 & 0.130 & 0.142 & 0.125 \\
\hline Jul & 0.116 & 0.126 & 0.137 & 0.149 & 0.132 \\
\hline Aug & 0.124 & 0.134 & 0.144 & 0.156 & 0.140 \\
\hline Sep & 0.144 & 0.155 & 0.165 & 0.176 & 0.160 \\
\hline Oct & 0.163 & 0.173 & 0.185 & 0.195 & 0.179 \\
\hline Nov & 0.171 & 0.181 & 0.191 & 0.200 & 0.186 \\
\hline Dec & 0.177 & 0.187 & 0.196 & 0.206 & 0.192 \\
\hline Mean & 0.140 & 0.150 & 0.160 & 0.172 & \\
\hline \multicolumn{5}{c}{ CD (Month, P $\mathbf{0 . 0 5})$} \\
\hline \multicolumn{5}{c}{ CD (Pair, P $\mathbf{0 . 0 5})$} \\
\hline
\end{tabular}

\begin{tabular}{|c|c|c|c|c|}
\hline \multicolumn{5}{|c|}{ Table.2 } \\
\hline \multicolumn{7}{|c|}{ Correlation coefficient of yield along with leaf Ca concentration } \\
\hline Month & $1^{\text {st }}$ pair & $2^{\text {nd }}$ pair & $3^{\text {rd }}$ pair & $4^{\text {th }}$ pair \\
\hline Jan & $-0.800^{* *}$ & $-0.804^{* *}$ & $-0.808^{* *}$ & $-0.810^{* *}$ \\
\hline Feb & $-0.773^{* *}$ & $-0.798^{* *}$ & $-0.804^{* *}$ & $-0.808^{* *}$ \\
\hline Mar & $-0.687^{* *}$ & $-0.743^{* *}$ & $-0.756^{* *}$ & $-0.783^{* *}$ \\
\hline Apr & $-0.750^{* *}$ & $-0.751^{* *}$ & $-0.793^{* *}$ & $-0.782^{* *}$ \\
\hline May & $-0.767^{* *}$ & $-0.802^{* *}$ & $-0.807^{* *}$ & $-0.792^{* *}$ \\
\hline Jun & $-0.779^{* *}$ & $-0.811^{* *}$ & $-0.796^{* *}$ & $-0.770^{* *}$ \\
\hline Jul & $-0.789^{* *}$ & $-0.796^{* *}$ & $-0.803^{* *}$ & $-0.775^{* *}$ \\
\hline Aug & $-0.797^{* *}$ & $-0.795^{* *}$ & $-0.787^{* *}$ & $-0.777^{* *}$ \\
\hline Sep & $-0.805^{* *}$ & $-0.801^{* *}$ & $-0.790^{* *}$ & $-0.793^{* *}$ \\
\hline Oct & $-0.808^{* *}$ & $-0.806^{* *}$ & $-0.806^{* *}$ & $-0.791^{* *}$ \\
\hline Nov & $-0.804^{* *}$ & $-0.805^{* *}$ & $-0.805^{* *}$ & $-0.798^{* *}$ \\
\hline Dec & $-0.807^{* *}$ & $-0.812^{* *}$ & $-0.806^{* *}$ & $-0.798^{* *}$ \\
\hline *significant at 5\% level & & & \\
\hline ***agnificant at 1\% level & & & \\
\hline
\end{tabular}




\begin{tabular}{|c|c|c|c|c|c|}
\hline \multicolumn{6}{|c|}{ Table.3 } \\
\hline \multicolumn{6}{|c|}{ Mean Mg concentration (\%) in leaves of litchi } \\
\hline Month & $\begin{array}{l}1^{\text {st }} \\
\text { pair }\end{array}$ & $\begin{array}{l}2^{\text {nd }} \\
\text { pair }\end{array}$ & $\begin{array}{l}3^{\text {rd }} \\
\text { pair }\end{array}$ & $\begin{array}{l}4^{\text {th }} \\
\text { pair }\end{array}$ & Mean \\
\hline Jan & 0.098 & 0.102 & 0.107 & 0.112 & 0.105 \\
\hline Feb & 0.106 & 0.111 & 0.116 & 0.121 & 0.114 \\
\hline Mar & 0.041 & 0.046 & 0.052 & 0.061 & 0.050 \\
\hline Apr & 0.046 & 0.050 & 0.054 & 0.063 & 0.053 \\
\hline May & 0.049 & 0.054 & 0.059 & 0.065 & 0.057 \\
\hline Jun & 0.055 & 0.060 & 0.066 & 0.072 & 0.063 \\
\hline Jul & 0.057 & 0.062 & 0.067 & 0.073 & 0.065 \\
\hline Aug & 0.063 & 0.068 & 0.074 & 0.080 & 0.071 \\
\hline Sep & 0.075 & 0.081 & 0.086 & 0.092 & 0.084 \\
\hline Oct & 0.077 & 0.082 & 0.089 & 0.093 & 0.085 \\
\hline Nov & 0.100 & 0.091 & 0.096 & 0.101 & 0.097 \\
\hline Dec & 0.084 & 0.089 & 0.093 & 0.098 & 0.091 \\
\hline Mean & 0.071 & 0.075 & 0.080 & 0.086 & \\
\hline \multicolumn{5}{|c|}{ CD $($ Month, $P=0.05)$} & 0.003 \\
\hline \multicolumn{5}{|c|}{ CD (Pair, P = 0.05) } & 0.002 \\
\hline \multicolumn{5}{|c|}{ CV $(\%)$} & 2.921 \\
\hline
\end{tabular}

\begin{tabular}{|c|c|c|c|c|}
\hline \multicolumn{5}{|c|}{ Table.4 } \\
\hline \multicolumn{6}{|c|}{ Correlation coefficient of yield along with leaf Mg concentration } \\
\hline Month & $1^{\text {st }}$ pair & $2^{\text {nd }}$ pair & $3^{\text {rd }}$ pair & $4^{\text {th }}$ pair \\
\hline Jan & $-0.801^{* *}$ & $-0.810^{* *}$ & $-0.813^{* *}$ & $-0.812^{* *}$ \\
\hline Feb & $-0.775^{* *}$ & $-0.809^{* *}$ & $-0.801^{* *}$ & $-0.808^{* *}$ \\
\hline Mar & $-0.664^{* *}$ & $-0.737^{* *}$ & $-0.751^{* *}$ & $-0.777^{* *}$ \\
\hline Apr & $-0.743^{* *}$ & $-0.815^{* *}$ & $-0.808^{* *}$ & $-0.800^{* *}$ \\
\hline May & $-0.771^{* *}$ & $-0.799^{* *}$ & $-0.804^{* *}$ & $-0.791^{* *}$ \\
\hline Jun & $-0.778^{* *}$ & $-0.809^{* *}$ & $-0.789^{* *}$ & $-0.767^{* *}$ \\
\hline Jul & $-0.788^{* *}$ & $-0.800^{* *}$ & $-0.802^{* *}$ & $-0.779^{* *}$ \\
\hline Aug & $-0.797^{* *}$ & $-0.791^{* *}$ & $-0.784^{* *}$ & $-0.779^{* *}$ \\
\hline Sep & $-0.806^{* *}$ & $-0.799^{* *}$ & $-0.791^{* *}$ & $-0.794^{* *}$ \\
\hline Oct & $-0.802^{* *}$ & $-0.815^{* *}$ & $-0.805^{* *}$ & $-0.788^{* *}$ \\
\hline Nov & $-0.805^{* *}$ & $-0.803^{* *}$ & $-0.800^{* *}$ & $-0.799^{* *}$ \\
\hline Dec & $-0.805^{* *}$ & $-0.810^{* *}$ & $-0.804^{* *}$ & $-0.797^{* *}$ \\
\hline *significant at 5\% level & & & \\
\hline$* *$ significant at 1\% level & & & \\
\hline
\end{tabular}




\begin{tabular}{|c|c|c|c|c|c|}
\hline \multicolumn{6}{|c|}{ Table.5 } \\
\hline \multicolumn{6}{|c|}{ Mean $S$ concentration $(\%)$ in leaves of litchi } \\
\hline Month & $\begin{array}{c}1^{\text {st }} \\
\text { pair }\end{array}$ & $\begin{array}{c}2^{\text {nd }} \\
\text { pair }\end{array}$ & $\begin{array}{c}3^{\text {rd }} \\
\text { pair }\end{array}$ & $\begin{array}{c}4^{\text {th }} \\
\text { pair }\end{array}$ & Mean \\
\hline Jan & 0.068 & 0.069 & 0.070 & 0.077 & 0.071 \\
\hline Feb & 0.069 & 0.071 & 0.071 & 0.078 & 0.072 \\
\hline Mar & 0.073 & 0.072 & 0.078 & 0.069 & 0.073 \\
\hline Apr & 0.076 & 0.072 & 0.077 & 0.079 & 0.076 \\
\hline May & 0.065 & 0.068 & 0.073 & 0.079 & 0.071 \\
\hline Jun & 0.070 & 0.069 & 0.078 & 0.080 & 0.074 \\
\hline Jul & 0.067 & 0.067 & 0.071 & 0.073 & 0.070 \\
\hline Aug & 0.069 & 0.069 & 0.072 & 0.081 & 0.073 \\
\hline Sep & 0.070 & 0.070 & 0.072 & 0.080 & 0.073 \\
\hline Oct & 0.070 & 0.071 & 0.072 & 0.080 & 0.073 \\
\hline Nov & 0.068 & 0.071 & 0.071 & 0.079 & 0.072 \\
\hline Dec & 0.066 & 0.069 & 0.070 & 0.078 & 0.071 \\
\hline Mean & 0.069 & 0.070 & 0.073 & 0.078 & \\
\hline \multicolumn{5}{|c|}{ CD $($ Month, $P=0.05)$} & 0.003 \\
\hline \multicolumn{5}{|c|}{ CD (Pair, $P=0.05)$} & 0.002 \\
\hline \multicolumn{5}{|c|}{ CV $(\%)$} & 3.609 \\
\hline
\end{tabular}

\section{Table.6}

\section{Correlation coefficient of yield along with leaf $\mathbf{S}$ concentration}

\begin{tabular}{|c|c|c|c|c|}
\hline Month & $1^{\text {st }}$ pair & $2^{\text {nd }}$ pair & $3^{\text {rd }}$ pair & $4^{\text {th }}$ pair \\
\hline Jan & 0.355 & 0.186 & 0.130 & 0.116 \\
\hline Feb & 0.395 & 0.270 & 0.201 & 0.305 \\
\hline Mar & -0.439 & -0.417 & -0.390 & -0.365 \\
\hline Apr & 0.042 & -0.246 & -0.128 & -0.096 \\
\hline May & -0.080 & -0.313 & -0.155 & -0.203 \\
\hline Jun & 0.162 & -0.202 & -0.010 & -0.123 \\
\hline Jul & 0.261 & -0.093 & 0.064 & 0.050 \\
\hline Aug & 0.211 & -0.061 & -0.030 & 0.068 \\
\hline Sep & 0.208 & -0.159 & -0.119 & -0.018 \\
\hline Oct & 0.162 & -0.017 & -0.055 & -0.016 \\
\hline Nov & 0.211 & -0.009 & 0.034 & 0.019 \\
\hline Dec & 0.270 & 0.057 & 0.003 & -0.062 \\
\hline *significant at 5\% level & & & \\
**significant at 1\% level & & & \\
\hline
\end{tabular}


Axial variability in leaf magnesium concentration

Data in Table 3 indicates that $4^{\text {th }}$ pair of leaves showed maximum $\mathrm{Mg}$ concentration followed by $3^{\text {rd }}, 2^{\text {nd }}$ and $1^{\text {st }}$ pair of leaves respectively. Concentrations of all pair of leaves were differed significantly. Similar trend was observed by Khera et al., (1981) in leaves of Peach, Sanyal and Mitra (1990) in litchi leaf cv. Bombai.

$\begin{array}{lll}\begin{array}{l}\text { Correlation } \\ \text { magnesium } \\ \text { productivity }\end{array} & \begin{array}{l}\text { coefficient between } \\ \text { concentration }\end{array} & \begin{array}{c}\text { leaf } \\ \text { and } \\ \text { crop }\end{array} \\ & & \end{array}$

Correlation coefficient (Table 4) clearly indicated that fruit yield was negatively and significantly correlated with $\mathrm{Mg}$. Highest significant correlation $\left(-0.815^{* *}\right)$ was observed with $2^{\text {nd }}$ pair of leaves in the month of April and October.

Temporal variability in leaf sulphur concentration

It is observed from the data (Table 5) that mean concentration of $\mathrm{S}$ reflects that it varied from 0.070 to $0.076 \%$. Maximum S concentration $(0.076 \%)$ was observed in the month of April and minimum $(0.070 \%)$ in the month of July.

An Increase was observed in the month of February to April, June and August. Concentration was stable during August to October and December to January. Decrease was observed in the month of May, July, November and December but significantly decrease was observed in the month of May and July. Concentration remained the same during January, May \& December; February \& November and March, August, September \& October. Concentration observed during March \& April and July \& August were at par. Arora et al., (1991) reported that $\mathrm{S}$ concentration in leaves of Grape varied from 0.04 to $0.29 \%$. Sanyal and Mitra (1990) suggested that leaf S concentration increased as the leaves matured in litchi fruits. Patel and Chadha (2002) were also suggested in grape that petiole $\mathrm{S}$ concentration decreased with advancement in growing season. This signified the role of $\mathrm{S}$ in flowering and fruiting, as it was required for synthesis of amino acids.

\section{Axial variability in leaf sulphur concentration}

From the Table 5 , it is clearly seen that that $4^{\text {th }}$ pair of leaves contained maximum concentration which was statistically superior among all pair of leaves. Concentration obtained from $3^{\text {rd }}$ pair and $2^{\text {nd }}$ pair of leaves was also differed significantly. Concentration obtained from the $1^{\text {st }}$ pair and $2^{\text {nd }}$ pair of leaves was at par. Our results were also in conformity with the findings observed by Khera et al., (1981) in leaves of Peach, Sanyal and Mitra (1990) in litchi leaf cv. Bombai.

Correlation coefficient between leaf sulphur concentration and crop productivity

Correlation coefficient values (Table 6) obtained for $\mathrm{S}$ reveals that no significant relationship exists with the fruit yields and leaf $\mathrm{S}$ concentration. Similar trend was observed by Verma and Bhandari (1990) in temperate peach. Higher r-value was observed for $1^{\text {st }}$ pair of leaves.

From the foregoing results of the present investigation, mean concentration in litchi leaf for secondary nutrients was in $0.162,0.082$ and 0.073 percent for $\mathrm{Ca}, \mathrm{Mg}$ and $\mathrm{S}$ respectively. Higher correlation coefficient between yield and concentration in leaves were observed positive and negative values both for $2^{\text {nd }} / 4^{\text {th }}$ pair of leaves depending upon the nature of mobility of nutrient in plant system. Among the secondary nutrient, it was observed that $\mathrm{Ca}$ was the most important secondary nutrient which influencing the food production of Litchi. Sampling for leaf during the month February to April or September to November was most suitable time for plant analysis. However, depending upon the prevalent fertilizers / manures practice, time and method of application of fertilizers / 
manures and fertigation etc one are to be looked critically for recommending leaf tissue based fertilizer recommendation for fruit crops.

\section{References}

Arora C.L., M. S.Brar, J. S. Brar and B. D. Kansal (1991). Nutrient status of Grape orchards in Punjab. Indian J. Hort.48 (3): 201-206.

Battelli, G. and G. Renzi (1990). A nutritional survey of Kiwi orchards in Northern Italy. Acta Hort. 282: 173-85.

Bhargava, B.S. (2002). Leaf analysis for nutrient Diagnosis, Recommendation and Management in fruit crops. J. Indian Soc. Soil Sci. 50(4):352-373

Chesnin, L. and C. H. Yien (1950). Turbidimetric determination of available Sulpher. Soil Sci Soc. Amer. Proc., 15: 149-151

Hesse, P.R. (1971). A text book of Soil

Chemical Analysis. John Murry

(Publishers) Ltd., London, U.K. PP.528.

Huang, W. T., Y. M. Huang, W. M. Hsiang, M. H. Chang, M. L. Lin, C. H. Wang and W. L. Lu (1998). Nutrition studies on Lychee (Litchi chinensis Sonn.) orchard in Central Taiwan. Journal of Agriculture Research of China 47: 388-407.

Khera, A. P., M. Makhija, S. D. Chitkara and K. S. Chauhan (1981). Development of leaf nutrient concentration standards for subtropical peach $(P$. persica). Haryana Agric. Univ. j. Res, 11

Laupassaki, M. H., I. I. Androulakis and S. M. Lionakis (1997). Effect of $\mathrm{P}$ and $\mathrm{K}$ fertilizers and date of sampling on the concentration of macro and microelements in the leaves of four Kiwi cultivars. Acta Hort. 444: 249-54.

Menzel, C. M., G. F. Haydon, V. J. Doogan and D. R. Simposon (1992b). Observation on the leaf nutrient status of Lychiee in Australia. Journal of South Africa Society for Horticulture Science, 2(2):86-88.

Menzel, C.M., M. L. Carseldine and D. R. Simpson (1987). The effect of leaf age on nutrient composition of non-fruiting litchi (Litchi chinensis Sonn.). J. Hort. Sci., 62: 273-79.

Patel, V.B. and K. L. Chadha (2002). Effect of sampling time on the Petiole nutrient composition in grape (Vitis vinifera L.). Ind. J. Hort., 59 (4): 349-354.

Porro, D., M. Stefanmi, G. Failla, Stringari, M. Tagliavini, G. H. Neilsen and P. Millard (1995). Optimal leaf sampling time in diagnosis of grapevine nutritional status. Acta Hort. 383: 135-142.

Rai, M., P. Dey, Vishal Nath and Bikash Das (2002). Litchi production Technology, Technical Bulletin 006 (NATP-PSR-42).

Sanyal, D. and S. K. Mitra (1990). Standardization of leaf sampling technique for mineral coposition of Litchi. cv. Bombai. Ind. J. Hort., 47(4): 371-375.

Shear, C.B. and M. Faust (1980). Nutritional ranges in deciduous tree fruits and nuts. Horticulture Review 2: 142 - 162.

Verma, K. S. and A. R. Bhandari (1990). Standardization of leaf sampling technique for Macro-nutrient elements in Temperate Peaches. Ind. J. Hort., 47(2): 140-153.

\section{How to cite this article:}

Ragini Kumari, Prabhakar Mahapatra and Sunil Kumar. 2019. Temporal and Axial Variations for Secondary Nutrient Concentrations in Leaves of Litchi. Int.J.Curr.Microbiol.App.Sci. 8(06): 18471854. doi: https://doi.org/10.20546/ijcmas.2019.806.220 